\title{
Impact of Fertility Levels and Weed Management Practices on Weed Dynamics and Yield of Lentil (Lens culinaris Medikus) under Eastern U.P. Conditions
}

\author{
Pradeep Kumar*, J.P. Singh, M.K. Singh and R.N. Meena \\ Department of Agronomy, Institute of Agricultural Sciences, Banaras Hindu University, \\ Varanasi (U.P.), India \\ *Corresponding author
}

\section{A B S T R A C T}

An experiment was conducted during the Rabi season of 2012-13 and 2013-14 to examine the effects of fertility levels and weed management practices on weed density, growth parameters and yield of lentil (Lens culinaris Medikus). The experiment was laid out in split-plot design comprising six main plot treatments viz. Control $\left(\mathrm{F}_{0}\right), 100 \%$ RDF $\left(\mathrm{F}_{1}\right)$, $75 \% \mathrm{RDF}+2 \%$ urea spray at pre-flowering and pod initiation stage $\left(\mathrm{F}_{2}\right), 75 \% \mathrm{RDF}+$ Plantgro $9 \mathrm{~kg} / \mathrm{ha}$ at 35, 50 and $65 \mathrm{DAS}$ as foliar spray $\left(\mathrm{F}_{3}\right), 100 \% \mathrm{RDF}+2 \%$ urea spray at pre-flowering and pod initiation stage $\left(\mathrm{F}_{4}\right), 100 \% \mathrm{RDF}+$ Plantgro $9 \mathrm{~kg} / \mathrm{ha}$ at 35,50 and 65

Keywords

Lentil, RDF, Foliar spray.

Article Info

Accepted:

04 September 2017

Available Online:

10 October 2017
DAS as foliar spray $\left(\mathrm{F}_{5}\right)$ and four sub-plot treatments viz. unweeded $\left(\mathrm{W}_{0}\right)$, weed free $\left(\mathrm{W}_{1}\right)$, pendimethalin $1 \mathrm{~kg}$ a.i./ha $\left(\mathrm{W}_{2}\right)$, imazethapyr $37.5 \mathrm{~g}$ a.i./ha $\left(\mathrm{W}_{3}\right)$. The major group of weeds found in the experimental field was Cyperus rotundus, Chenopodium album, Solanum nigrum and Cynodon dactylon. The results indicated that fertility levels and weed management had a significant effect on weed population dynamics and lentil crop. Higher yield attributes, yield and harvest index was recorded with the treatment $75 \%$ RDF + Plantgro $9 \mathrm{~kg} / \mathrm{ha}$. Higher grain yield (1283.08 kg/ha) was recorded with $75 \% \mathrm{RDF}+$ Plantgro $9 \mathrm{~kg} / \mathrm{ha}$ whereas straw yield $(2140.64 \mathrm{~kg} / \mathrm{ha})$, net returns 23218.09 (Rs./ha) and $\mathrm{B}: \mathrm{C}$ ratio (2.29) was obtained with $100 \% \mathrm{RDF}+2 \%$ urea spray. The increase in yield was $11.41 \%$ and $29.83 \%$ over $100 \%$ RDF $+2 \%$ urea spray and control respectively. Highest $\mathrm{N}, \mathrm{P}, \mathrm{K}$ uptake $(50.08,7.29$ and $22.92 \mathrm{~kg} / \mathrm{ha})$ respectively was recorded with $75 \% \mathrm{RDF}+$ Plantgro $9 \mathrm{~kg} / \mathrm{ha}$. Total weed count and dry weight decreased significantly with the application of post-emergence application of imazethapyr $37.5 \mathrm{~g} / \mathrm{ha}$ and was comparable to pendimethalin $1 \mathrm{~kg} / \mathrm{ha}$. Highest weed control efficiency of $68.87 \%$ was recorded with imazethapyr $37.5 \mathrm{~g} / \mathrm{ha}$. Higher grain yield $(1088.05 \mathrm{~kg} / \mathrm{ha})$, straw yield $(2121.43 \mathrm{~kg} / \mathrm{ha})$, net returns 22625.76 and B: C ratio (2.35) was recorded with imazethapyr $37.5 \mathrm{~g} / \mathrm{ha}$. This treatment also recorded the highest $\mathrm{N}(39.84 \mathrm{~kg} / \mathrm{ha}), \mathrm{P}(4.88 \mathrm{~kg} / \mathrm{ha}), \mathrm{K}(15.93 \mathrm{~kg} / \mathrm{ha})$ uptake and protein content $(22.72 \%)$ of lentil.

\section{Introduction}

At the global level, though India's share in lentil production is quite large $(30 \%)$, yet the production $(0.95 \mathrm{mt})$ and productivity level $(633.33 \mathrm{~kg} / \mathrm{ha})$ in the country is substantially low (FAOSTAT, 2014). The low average yield might be due to poor level of crop management, growing lentil on marginal lands with low fertilizer inputs and inadequate 
weed management. Foliar application is regarded as a preferred solution when the quick supply of nutrients is hindered or the soil conditions are conducive for the absorption of nutrients (Salisbury and Ross, 1995). Urea is the most suitable nitrogen source for foliar application due to its low salt index and high solubility in comparison to other nitrogen sources Plant GRO MAGIC is a fertilizer product which is a multinutrient water soluble fertilizer ( $57.1 \%$ total nutrients) and includes nitrogen, phosphorus and potassium as primary nutrients. It has been found that weeds reduce yield of lentil to the extent of 73\% (Phogat et al., 2003) and under high densities of weeds losses can reach even up to $100 \%$. Weed infestation in lentil is high due to its slow initial growth, short stature and shallow root system. The most effective method of controlling weeds in lentil is hand weeding. But, this technique is feasible only on small farms and under sufficient labour availability. The use of herbicides as an alternative to hand weeding can be feasible and more economical than hand weeding. Preemergence herbicides like pendimethalin are effective only for a period of initial 30 days and at later stages, crop gets infested with weeds. Therefore, the use of post-emergence herbicide needs to be advocated in lentil. There is a need to develop most effective and economical fertilizer management and weed control practices for obtaining higher yield as well as profitability. Keeping these facts in view, the present experiment was designed to determine the best suitable fertilizer and weed management technique for lentil crop.

\section{Materials and Methods}

Field experiment was conducted during the winter season of 2012-13 and 2013-14 at dryland research farm of Banaras Hindu University, Varanasi (U.P.) to examine the performance of lentil under varying fertility levels and weed management treatments. The experimental site is located at $25^{0} 18^{\prime}$ North latitude, $83^{0} 3^{\prime}$ East longitude and at altitude of 76.60 meter above the mean sea level (MSL) in the Northern Gangetic Alluvial Plain. A composite representative soil sample was collected and was analysed for physicochemical properties. The soil was clay loam in texture with $\mathrm{pH} 7.31$ (1:25 soil and water ratio), $0.37 \%$ organic carbon (Walkley and Black, 1937), $212.50 \mathrm{~kg} / \mathrm{ha}$ available nitrogen (Subbiah and Asija, 1956), $25.17 \mathrm{~kg} / \mathrm{ha}$ available phosphorus (Olsen et al., 1954) and $234.15 \mathrm{~kg} / \mathrm{ha}$ potassium (Jackson, 1973) before the start of the experiment. The experiment was replicated thrice in split-plot design with six fertility levels viz. Control $\left(\mathrm{F}_{0}\right), 100 \%$ RDF $\left(\mathrm{F}_{1}\right), 75 \% \mathrm{RDF}+2 \%$ urea spray at pre-flowering and pod initiation $\left(\mathrm{F}_{2}\right)$, $75 \% \mathrm{RDF}+$ Plantgro $9 \mathrm{~kg} / \mathrm{ha}$ at 35, 50 and 65 DAS as foliar spray (F3), $100 \% \mathrm{RDF}+2 \%$ urea spray at pre-flowering at pod initiation $\left(\mathrm{F}_{4}\right), 100 \% \mathrm{RDF}+$ Plantgro $9 \mathrm{~kg} / \mathrm{ha}$ at 35,50 and 65 DAS as foliar spray $\left(\mathrm{F}_{5}\right)$ and four weed management practices viz., Unweeded $\left(\mathrm{W}_{0}\right)$, weed free $\left(\mathrm{W}_{1}\right)$, pendimethalin 1.0 $\mathrm{kg} / \mathrm{ha}\left(\mathrm{W}_{2}\right)$, imazethapyr $37.5 \mathrm{~g} / \mathrm{ha}\left(\mathrm{W}_{3}\right)$. A uniform dose of $20,40,30 \mathrm{~kg} \mathrm{~N}, \mathrm{P}_{2} \mathrm{O}_{5}$, $\mathrm{K}_{2} \mathrm{O} /$ ha was applied to different plots as per the treatment requirements through urea, Single super phosphate and Muriate of potash respectively. Full dose of recommended fertilizers were applied as basal before sowing. Lentil variety HUL-57 (MalviyaVishwanath) was sown on 23 Novemeber in 2013 and 21 November in 2014, respectively using a seed rate of $40 \mathrm{~kg} / \mathrm{ha}$ at row spacing of $25 \times 5 \mathrm{~cm}$ and following all standard package and practices. Hand weeing was done with the help of khurpi at an interval of 25 days or whenever weeds were observed in weed free plots. Pendimethalin was applied as pre-emergence using Knapsack sprayer fitted with flat fan nozzle by mixing 500 litres of water/ha. Post-emergence herbicide Imazethapyr was applied at 2-4 leaf stage of weed. The observations on weed dry matter 
were taken randomly from $0.5 \mathrm{~m} \mathrm{x} 0.5 \mathrm{~m}$ quadrate from 2 spots from each plot at the time of harvest. The weed samples were sundried for 2-3 days and then dried in oven at $70^{\circ} \mathrm{C}$ for 48 hours to obtain a constant weight. The data on weed experiment were subjected to square root transformation $\sqrt{\mathrm{x}+0.5}$ for uniformity. The crop was harvested at 24 March in 2013 and 22 March in 2014 respectively.

Weed free and unweeded control treatments were kept for comparison with different treatments. Yield attributes viz. number of seeds/pod, test weight and yield i.e. grain yield ( $\mathrm{kg} / \mathrm{ha})$ and straw yield ( $\mathrm{kg} / \mathrm{ha}$ ) were recorded at harvest during both the years. Net returns were calculated by using prevailing prices of inputs and outputs during the respective crop season. Benefit: cost ratio was calculated by dividing the net returns from the cost of cultivation. The data was analysed using standard ANOVA for split-plot design and the significance of differences between the treatments means were compared with critical differences at $5 \%$ level of probability.

\section{Results and Discussion}

\section{Weed flora}

Weed flora of the experimental field consisted of grasses, sedges and broad leaved weeds. The dominant weed flora included Cyperus spp. among sedges, Chenopodium album and Solanum nigrum among broad-leaved weeds and Cynodon dactylon among the grassy weeds. Parthenium hysterophorus, Fumaria parviflora, Anagallis arvensis, Vicia sativa, Melilotus indica, Medicago polymorpha were found in negligible presence. Sedges dominated the experimental field to the extent of $42 \%$ followed by broad-leaved and grassy weeds. These results are supported with the findings of Bhowmick et al., (2010). This might be due to the reason that application of pre-emergence herbicide might have controlled the weeds at the initial stage of the crop. Further, pendimethalin is used in crops for selective control of annual broad leaved weeds and grasses but it is ineffective for sedges.

\section{Effect on weeds}

It was observed that lowest weed count and dry weight of weeds was recorded with $75 \%$ $\mathrm{RDF}+$ Plantgro $9 \mathrm{~kg} \mathrm{ha}^{-1}$ and was at par with the application of $100 \% \mathrm{RDF}+2 \%$ urea spray. However, all the fertility level treatments were significantly superior to control in minimizing the total weed count of all weeds. Weed management treatments significantly influenced total weed count and total weed dry weight. Significantly lowest weed count and dry weight was noted under the post-emergence application of imazethapyr $37.5 \mathrm{~g} / \mathrm{ha}$ and was at par with the application of pendimethalin $1 \mathrm{~kg} / \mathrm{ha}$ and highest with unweeded control. Effectiveness of post-emergence herbicides for weed control in various pulse crops has been reported by Kumar (2008). However, neither of the herbicides was as effective as hand weeding in recording the lower total weed count.

\section{Weed control efficiency (\%)}

The higher weed control efficiency was achieved under application of $75 \% \mathrm{RDF}+$ Plantgro $9 \mathrm{~kg} \mathrm{ha}^{-1}$ and was at par with $100 \%$ $\mathrm{RDF}+2 \%$ urea spray application. Weed dry matter was reduced under highest level of nutrients. Similar trend was reported by Prajapati et al., (2003) in Gujarat. Among the herbicidal application treatments, the highest weed control efficiency was associated with weed free which might be attributed due to its effective control of complex weed flora viz., grasses, sedges and broad-leaved weeds in which the broad leaved weeds were 
suppressed before weed seed sprout. Among the herbicidal treatments, higher weed control efficiency was obtained with post-emergence application of imazethapyr $37.5 \mathrm{~g} / \mathrm{ha}$. This might be due to lower weed population and reduced dry matter production of weeds which were effectively controlled by imazethapyr (Table 1).

Table.1 Total weed count, weed dry weight, weed control efficiency and nutrient depletion by weeds as influenced by fertility levels and weed management (pooled data of two years)

\begin{tabular}{|c|c|c|c|c|c|c|}
\hline \multirow[t]{2}{*}{ Treatments } & \multirow{2}{*}{$\begin{array}{c}\text { Total } \\
\text { weed } \\
\text { count } \\
\left(\text { No. } \mathbf{m}^{-2}\right)\end{array}$} & \multirow{2}{*}{$\begin{array}{l}\text { Total weed } \\
\text { dry weight } \\
\left(\mathrm{g} \mathrm{m}^{-2}\right)\end{array}$} & \multirow{2}{*}{$\begin{array}{c}\text { Weed } \\
\text { control } \\
\text { efficiency } \\
(\%)\end{array}$} & \multicolumn{3}{|c|}{ Nutrient depletion (kg/ha) } \\
\hline & & & & $\mathbf{N}$ & $\mathbf{P}$ & $\mathbf{K}$ \\
\hline \multicolumn{7}{|l|}{ A. Fertility levels } \\
\hline$F_{0}$ Control & $\begin{array}{c}6.99 \\
(70.34) \\
\end{array}$ & $\begin{array}{c}7.03 \\
(68.26) \\
\end{array}$ & 56.40 & 4.86 & 0.75 & 2.31 \\
\hline $\mathrm{F}_{1} 100 \% \mathrm{RDF}$ & $\begin{array}{c}6.40 \\
(57.82)\end{array}$ & $\begin{array}{c}6.30 \\
(52.88)\end{array}$ & 60.03 & 3.26 & 0.43 & 1.50 \\
\hline $\begin{array}{l}\mathrm{F}_{2} 75 \% \mathrm{RDF}+2 \% \text { urea } \\
\text { spray at pre-flowering } \\
\text { and pod initiation }\end{array}$ & $\begin{array}{c}6.72 \\
(63.57)\end{array}$ & $\begin{array}{c}6.42 \\
(54.94)\end{array}$ & 56.99 & 3.61 & 0.51 & 1.67 \\
\hline $\begin{array}{l}F_{3} 75 \% \text { RDF + Plantgro } \\
9 \mathrm{~kg} / \mathrm{ha} \text { at } 35,50,65 \\
\text { DAS as foliar spray }\end{array}$ & $\begin{array}{c}5.86 \\
(48.99)\end{array}$ & $\begin{array}{c}5.79 \\
(45.49)\end{array}$ & 60.25 & 2.57 & 0.35 & 1.16 \\
\hline $\begin{array}{l}\mathrm{F}_{4} 100 \% \text { RDF + } 2 \% \\
\text { urea spray at pre- } \\
\text { flowering and pod } \\
\text { initiation }\end{array}$ & $\begin{array}{c}6.16 \\
(53.49)\end{array}$ & $\begin{array}{c}5.99 \\
(47.62)\end{array}$ & 60.14 & 2.98 & 0.40 & 1.35 \\
\hline $\begin{array}{l}\text { F }_{5} 100 \% \text { RDF + } \\
\text { Plantgro } 9 \mathrm{~kg} / \mathrm{ha} \text { at } 35, \\
50,65 \text { DAS as foliar } \\
\text { spray }\end{array}$ & $\begin{array}{c}6.73 \\
(65.51)\end{array}$ & $\begin{array}{c}6.72 \\
(62.05)\end{array}$ & 56.47 & 4.01 & 0.59 & 1.92 \\
\hline S Em \pm & 0.03 & 0.04 & - & 0.14 & 0.007 & 0.018 \\
\hline $\mathrm{CD}(\mathbf{P}=\mathbf{0 . 0 5})$ & 0.09 & 0.12 & - & 0.45 & 0.022 & 0.053 \\
\hline \multicolumn{7}{|l|}{ B. Weed management } \\
\hline $\mathrm{W}_{0}$ Unweeded & $\begin{array}{c}12.70 \\
(161.49)\end{array}$ & $\begin{array}{c}11.52 \\
(133.29)\end{array}$ & 0.00 & 7.16 & 1.03 & 3.38 \\
\hline $\mathrm{W}_{1}$ Weed free & $\begin{array}{c}0.71 \\
(0.00)\end{array}$ & $\begin{array}{c}0.71 \\
(0.00)\end{array}$ & 100.00 & 0.00 & 0.00 & 0.00 \\
\hline $\begin{array}{l}\mathrm{W}_{2} \text { Pendimethalin } 1.0 \\
\mathrm{~kg} / \mathrm{ha}\end{array}$ & $\begin{array}{c}6.91 \\
(47.47) \\
\end{array}$ & $\begin{array}{c}6.84 \\
(46.54) \\
\end{array}$ & 64.64 & 4.33 & 0.61 & 1.96 \\
\hline $\begin{array}{l}\text { W/ Imazethapyr } 37.5 \\
\text { g/ha }\end{array}$ & $\begin{array}{c}5.59 \\
(30.85)\end{array}$ & $\begin{array}{c}6.43 \\
(40.93)\end{array}$ & 68.87 & 2.70 & 0.39 & 1.26 \\
\hline S Em \pm & 0.02 & 0.03 & - & 0.10 & 0.008 & 0.015 \\
\hline $\mathrm{CD}(\mathrm{P}=0.05)$ & 0.06 & 0.07 & - & 0.27 & 0.023 & 0.044 \\
\hline
\end{tabular}


Table.2 Growth attributes, yield attributes and yield of lentil as influenced by fertility levels and weed management (Pooled data of two years)

\begin{tabular}{|c|c|c|c|c|c|c|c|c|c|}
\hline \multirow[t]{2}{*}{ Treatment } & \multicolumn{3}{|c|}{ Growth attributes (90 DAS) } & \multicolumn{3}{|c|}{ Yield attributes } & \multicolumn{2}{|c|}{ Yield } & \multirow{2}{*}{$\begin{array}{c}\text { Harvest } \\
\text { index } \\
(\%)\end{array}$} \\
\hline & $\begin{array}{l}\text { Plant } \\
\text { height } \\
\text { (cm) }\end{array}$ & $\begin{array}{c}\text { Branches/ } \\
\text { plant }\end{array}$ & $\begin{array}{c}\text { Dry matter } \\
\text { accumulation } \\
\left(\mathbf{g} / \mathbf{m}^{2}\right)\end{array}$ & $\begin{array}{c}\text { No. of } \\
\text { pods/plant }\end{array}$ & $\begin{array}{c}\text { No. of } \\
\text { seeds/pod }\end{array}$ & $\begin{array}{l}\text { Test } \\
\text { weight } \\
\text { (g) }\end{array}$ & $\begin{array}{l}\text { Grain } \\
\text { yield } \\
(\text { kg/ha) }\end{array}$ & $\begin{array}{c}\text { Straw } \\
\text { yield } \\
\text { (kg/ha) }\end{array}$ & \\
\hline \multicolumn{10}{|l|}{ A. Fertility levels } \\
\hline $\mathbf{F}_{\mathbf{0}}$ Control & 30.21 & 5.27 & 45.07 & 34.18 & 1.73 & 20.29 & 900.33 & 1806.14 & 33.19 \\
\hline $\mathrm{F}_{1} \mathbf{1 0 0 \%} \mathrm{RDF}$ & 35.36 & 5.71 & 64.61 & 57.42 & 1.85 & 23.00 & 1096.98 & 1972.25 & 35.94 \\
\hline $\begin{array}{l}\mathrm{F}_{2} \mathbf{7 5 \%} \mathrm{RDF}+2 \% \text { urea spray } \\
\text { at pre-flowering and pod } \\
\text { initiation }\end{array}$ & 36.82 & 6.66 & 74.21 & 54.68 & 1.82 & 22.40 & 1027.41 & 1993.29 & 34.04 \\
\hline $\begin{array}{l}\text { F }_{3} 75 \% \text { RDF + Plantgro } 9 \\
\text { kg/ha at 35, 50, } 65 \text { DAS as } \\
\text { foliar spray }\end{array}$ & 36.95 & 7.01 & 79.80 & 62.26 & 1.98 & 25.20 & 1283.08 & 2140.64 & 37.96 \\
\hline $\begin{array}{l}\mathrm{F}_{4} 100 \% \mathrm{RDF}+2 \% \text { urea } \\
\text { spray at pre-flowering and } \\
\text { pod initiation }\end{array}$ & 37.01 & 7.15 & 84.15 & 58.79 & 1.87 & 23.65 & 1136.59 & 2357.74 & 32.82 \\
\hline $\begin{array}{l}\text { F }_{5} 100 \% \text { RDF + Plantgro } 9 \\
\text { kg/ ha at 35, 50, } 65 \text { DAS as } \\
\text { foliar spray }\end{array}$ & 38.23 & 7.61 & 89.27 & 45.43 & 1.78 & 21.40 & 1028.37 & 2312.82 & 30.84 \\
\hline S Em \pm & 0.62 & 0.09 & 1.31 & 0.90 & 0.02 & 0.43 & 20.80 & 32.33 & 0.48 \\
\hline $\mathrm{CD}(\mathrm{P}=0.05)$ & 1.82 & 0.26 & 3.87 & 2.67 & 0.06 & 1.27 & 61.37 & 101.87 & 1.40 \\
\hline \multicolumn{10}{|l|}{ B. Weed management } \\
\hline $\mathbf{W}_{0}$ Unweeded & 32.83 & 5.97 & 66.15 & 37.82 & 1.73 & 21.20 & 953.66 & 1991.38 & 32.67 \\
\hline$W_{1}$ Weed free & 38.18 & 7.22 & 82.41 & 61.19 & 1.97 & 24.01 & 1230.94 & 2167.24 & 36.46 \\
\hline $\mathrm{W}_{2}$ Pendimethalin $1.0 \mathrm{~kg} / \mathrm{ha}$ & 35.42 & 6.41 & 69.24 & 53.74 & 1.79 & 22.28 & 1042.53 & 2108.54 & 33.48 \\
\hline $\mathrm{W}_{3}$ Imazethapyr $37.5 \mathrm{~g} / \mathrm{ha}$ & 36.61 & 6.67 & 73.65 & 55.75 & 1.86 & 23.14 & 1088.05 & 2121.43 & 33.92 \\
\hline $\mathbf{S ~ E m} \pm$ & 0.18 & 0.04 & 0.57 & 0.68 & 0.01 & 0.09 & 12.33 & 61.11 & 0.80 \\
\hline $\mathrm{CD}(\mathrm{P}=0.05)$ & 0.51 & 0.11 & 1.61 & 1.93 & 0.03 & 0.26 & 34.75 & 175.02 & 2.26 \\
\hline
\end{tabular}


Table.3 Effect of fertility levels and weed management on nutrient uptake and protein content of lentil (pooled data of two years)

\begin{tabular}{|c|c|c|c|c|}
\hline \multirow[t]{2}{*}{ Treatment } & \multicolumn{3}{|c|}{ Nutrient uptake by crop (kg/ha) } & \multirow{2}{*}{$\begin{array}{l}\text { Protein content } \\
\qquad(\%)\end{array}$} \\
\hline & $\mathbf{N}$ & $\mathbf{P}$ & $\mathbf{K}$ & \\
\hline \multicolumn{5}{|l|}{ A. Fertility levels } \\
\hline$F_{0}$ Control (No fertilizer) & 30.17 & 2.60 & 6.40 & 20.82 \\
\hline $\mathrm{F}_{1} 100 \% \mathrm{RDF}$ & 39.96 & 5.32 & 16.69 & 22.60 \\
\hline $\begin{array}{l}\mathrm{F}_{2} 75 \% \mathrm{RDF}+2 \% \text { urea spray at pre-flowering and } \\
\text { pod initiation }\end{array}$ & 36.96 & 4.14 & 13.56 & 22.29 \\
\hline $\begin{array}{l}\mathrm{F}_{3} 75 \% \mathrm{RDF}+\text { Plantgro } 9 \mathrm{~kg} / \mathrm{ha} \text { at } 35,50,65 \mathrm{DAS} \text { as } \\
\text { foliar spray }\end{array}$ & 50.08 & 7.29 & 22.92 & 24.27 \\
\hline $\begin{array}{l}\mathrm{F}_{4} \mathbf{1 0 0 \%} \mathrm{RDF}+2 \% \text { urea spray at pre-flowering } \\
\text { and pod initiation }\end{array}$ & 42.60 & 6.11 & 18.47 & 23.25 \\
\hline $\begin{array}{l}\mathrm{F}_{5} \mathbf{1 0 0 \%} \mathrm{RDF}+\text { Plantgro } 9 \mathrm{~kg} / \mathrm{ha} \text { at } 35,50,65 \mathrm{DAS} \\
\text { as foliar spray }\end{array}$ & 36.30 & 4.08 & 12.48 & 21.97 \\
\hline $\mathrm{SEm} \pm$ & 1.15 & 0.16 & 0.47 & 0.19 \\
\hline $\mathrm{CD}(\mathrm{P}=\mathbf{0 . 0 5})$ & 3.63 & 0.50 & 1.49 & 0.56 \\
\hline \multicolumn{5}{|l|}{ B. Weed management } \\
\hline $\mathbf{W}_{0}$ Unweeded & 31.74 & 3.22 & 7.76 & 20.72 \\
\hline $\mathrm{W}_{1}$ Weed free & 49.30 & 7.41 & 22.81 & 24.90 \\
\hline $\mathrm{W}_{2}$ Pendimethalin $1.0 \mathrm{~kg} / \mathrm{ha}$ & 36.51 & 4.18 & 13.85 & 21.78 \\
\hline $\mathrm{W}_{3}$ Imazethapyr $37.5 \mathrm{~g} / \mathrm{ha}$ & 39.84 & 4.88 & 15.93 & 22.72 \\
\hline $\mathrm{SEm} \pm$ & 0.59 & 0.08 & 0.27 & 0.07 \\
\hline $\mathrm{CD}(\mathrm{P}=0.05)$ & 1.68 & 0.24 & 0.77 & 0.21 \\
\hline
\end{tabular}




\section{Growth attributes}

Among the fertility levels, 100\% RDF +Plantgro $9 \mathrm{~kg} / \mathrm{ha}$ recorded higher growth attributes (plant height, number of branches/plant and dry matter accumulation/plant) than $75 \% \quad \mathrm{RDF}+$ Plantgro $9 \mathrm{~kg} / \mathrm{ha}$ (Table 2). Similar results were obtained by Shivran and Ahlawat (2000) and Chandel et al., (2002).This might be attributed to higher supply of nutrients which led to greater vegetative growth and dry matter accumulation.

All the treatments of weed management showed significant enhancement in growth attributes over unweeded. Higher value of all the growth attributes was recorded with the application of imazethapyr $37.5 \mathrm{~g} / \mathrm{ha}$ and was comparable to pendimethalin $1 \mathrm{~kg} / \mathrm{ha}$. This can be attributed to better control of weeds by imazethapyr at vegetative growth stage of crop which provided enough resources to the crop and a competition free environment.

\section{Yield attributes and yield}

Different fertility levels produced significant impact on yield attributes and yield of lentil over control. Significantly higher number of pods/plant, seeds/pod and test weight was recorded with the application of $75 \% \mathrm{RDF}+$ Plantgro $9 \mathrm{~kg} / \mathrm{ha}$ and it was at par with the application of $100 \% \mathrm{RDF}+2 \%$ urea spray (Table 2). $75 \%$ RDF + Plantgro $9 \mathrm{~kg} / \mathrm{ha}$ increased lentil grain yield increased to the tune of $11.41 \%$ and $29.83 \%$ over $100 \%$ RDF $+2 \%$ urea spray and control respectively.

However, all the fertility levels proved significantly superior to control in increasing grain yield, straw yield and harvest index. Higher grain yield could be due to better development of yield attributes viz. pods/plant, seeds/pod and test weight. This might also be due to timely supply of macro and micronutrients in required amounts which was supplied through plantgro. Similar results were obtained by Singh et al., (2014).Weed management treatments showed significant enhancement of yield attributes over control during both the years.

Among herbicide treatments, higher yield attributes and yield was recorded with the application of imazethapyr $37.5 \mathrm{~g} / \mathrm{ha}$ and was comparable with pendimethalin $1 \mathrm{~kg} / \mathrm{ha}$. This might be due to better suppression of weeds. Among controls, weedy check recorded significantly lower grain and straw yield compared to weed free treatment during both the years. All the weed control treatments were superior in terms of returns over weedy check.

\section{Nutrient depletion by weeds and nutrient uptake by crop}

It was observed that minimum nutrient depletion by weeds and highest uptake of nutrient by crop was recorded with the application of $75 \%$ RDF + Plantgro $9 \mathrm{~kg} / \mathrm{ha}$ and was comparable to $100 \% \mathrm{RDF}+2 \%$ urea spray. All the fertility level treatments were significantly superior to control in minimizing the nutrient depletion by weeds and maximizing the nutrient uptake by crop (Table 3). This can be attributed to better availability of nutrients. Since the uptake of nutrient is a function of dry matter and nutrient content, the higher biological yield resulted into higher nutrient uptake by crop. Herbicidal application of exhibited significant effect on nutrient depletion by weed, nutrient uptake by crop and protein content in grain. Minimum nutrient depletion, highest nutrient uptake and protein content of lentil was observed under imazethapyr $37.5 \mathrm{~g} / \mathrm{ha}$. Unweeded control recorded lowest nutrient uptake. These results are in confirmation with the findings of Singh et al., (2013.). It is inferred that application of $100 \% \mathrm{RDF}+2 \%$ 
urea spray or $75 \% \mathrm{RDF}+$ Plantgro $9 \mathrm{~kg} / \mathrm{ha}$ and weed management with imazethapyr 37.5 $\mathrm{g} / \mathrm{ha}$ found to be most suitable for lentil crop.

\section{References}

Bhowmick, M.K., Bag, M.K., and Islam, S. 2010. Integrated weed management in lentil (Lens culinaris Medikus), The Journal of Plant Protection Sciences, 2 (2), 88-91.

Chandel, R.S., Singh, R., Singh, R. S., and Singh, O.N. 2002. Influence of nitrogen levels and Rhizobium inoculation on yield, quality and nitrogen uptake of French bean (Phaseolus vulgaris L.), Research on Crops, 3, 524-528.

FAOSTAT, 2014. Fao Statistical Database, Retrieved from http:// www.fao.org.

Jackson, M.L., 1973. Soil Chemical Analysis. Prentice Hall of India Pvt. Ltd., New Delhi, India, pp. 183-204.

Kumar, N., 2008. Post-emergence Herbicides for Pulses, Indian Institute of Pulses Research Newsletter, 19, (4), 2.

Olsen, S.R., Cole, C.V., Watanabe, F.S. and Dean, L. 1954. Estimation of available phosphorus in soil by extraction with sodium carbonate. Circular 933, United States Department of Agriculture, Washington, DC.

Phogat, S.B., Kumar S., Sangwan, N., and Hooda, R.S. 2003. Effect of herbicides and cultural practices on weed flora of lentil, Indian Journal of Pulses Research, 16(2), 119-121.

Prajapati, M.P., Patel, H. A., Prajapati, B. H., Patel, L. R. 2004. Studies on nutrient uptake and yield of French bean (Phaseolus vulgaris L.) as affected by weed control methods and nitrogen levels,
Legume Research, 27, 99-102.

Prajapati, M.P., Patel, L.R., and Patel, B.M. 2003. Effects of integrated weed management and nitrogen levels on weeds and productivity of French bean (Phaseolus vulgaris L.) under North Gujarat conditions, Legume Research, 26, 79-84.

Salisbury, F.B., and Ross, C.W. 1995. Plant Physiology, 3rd ed. Wadsworth, Belmont, CA. 540 p.

Shivran, P.L., Ahlawat, I.P.S., Shivran, D.R. 2000. Effect of phosphors and sulphur on pigeonpea-wheat cropping sequence, Indian Journal of Agronomy, 45(1), 25-30.

Singh, D., and Singh, R.P. 2014. Effect of integrated nutrient management on growth, physiological parameters and productivity of lentil (Lens culinaris Medik.), International Journal of Agricultural Sciences, 10(1): 175-178.

Singh, M., Kumar, S., Kumar, R., Singh, R., and Kumar, S. 2013. Effect of post emergence herbicides on nutrients uptake by field pea and associated weeds, International Journal of Agricultural Sciences, 2013, 9(2), 710-712.

Singh, M.D., and Singh, V.K.R. 2003. Weed dynamics and grain yield of bold seeded lentil as influenced by weed management practices, Indian Journal of Weed Science, 35(1\&2), 148-150.

Subbiah, B.V., and Asija, G.L. 1956. A rapid procedure for assessment of available nitrogen in rice soils, Current Science 25: 259-60.

Walkley, A.J., and Black, I.A. 1934. An examination of the Degtjareff method for determination of soil organic matter and a proposed modification of the chronic acid titration method, Soil Science 37: 29-38.

\section{How to cite this article:}

Pradeep Kumar, J.P. Singh, M.K. Singh and Meena, R.N. 2017. Impact of Fertility Levels and Weed Management Practices on Weed Dynamics and Yield of Lentil (Lens culinaris Medikus) under Eastern U.P. Conditions. Int.J.Curr.Microbiol.App.Sci. 6(10): 358-365.

doi: https://doi.org/10.20546/ijcmas.2017.610.044 